\title{
Price and volatility persistence of the US REITs market
}

\author{
Oluwasegun B. Adekoya ${ }^{1 *}$ D, Gabriel O. Oduyemi ${ }^{2}$ and Johnson A. Oliyide ${ }^{1}$
}

\begin{abstract}
This study revisits the issue of REITs market efficiency for the US having discovered two notable gaps. Noting the complexities, structural changes and nonlinearities in modern financial markets, we employ the fractional integration technique which performs better than other commonly used techniques in the presence of structural breaks, fractional integration, trend-stationarity and regime switching in time series. Summarizing our results, we find that the US REITs market is efficient in the overall sample. However, when the data are splitted, market efficiency only occurs in the pre-crisis period, but becomes less so during the crisis and post-crisis periods. In addition, evidence of mean reverting long-memory behavior is established for REITs volatility, although mean reversion is slower during and after the crisis. These results are robust to different data measurement and have crucial policy implications for potential investors and relevant policy makers.
\end{abstract}

Keywords: REITs, Market efficiency, Fractional integration, Long memory, 2008 Global financial crisis

JEL classification: G14, G15

\section{Introduction}

Real Estate Investment Trusts, commonly shortened as REITs, is one of the fastest growing components of portfolio construction in many developed and emerging economies of the world in recent years. In fact, its role in the process of investment management in these countries has been increasingly significant [7]. Liu et al. [28] note that legislation and issuance of REITs have been implemented by not less than 37 countries as at October, 2008. The reason for this wide and increasing acceptance of REITs in recent times is likely to be the high level of security guaranteed on it. For instance, Chen and Shen [12] reveal that out of the total taxable income on REITs, a minimum of $90 \%$ must be distributed to the investors as dividends on annual basis. Lee and Stenvenson (2005) also point out that, to a reasonable degree, REITs stands between the fixed income sector and equities by

\footnotetext{
*Correspondence: adekoyaob@gmail.com

${ }^{1}$ Department of Economics, Federal University of Agriculture, Abeokuta, Nigeria

Full list of author information is available at the end of the article
}

providing hybrid form of investment. All these, among others, have increasingly motivated potential investors to be active participants in the sector over the years. Hence, the growing interest of investors in REITs, coupled with its integral role in portfolio management and diversification, has been the major drive behind the overwhelming empirical focus geared toward the examination of the behavior of the asset recently.

The increasing consideration of REITs in many countries has been followed by the assessment of the efficiency of its market by various researchers. However, based on specific peculiarities of each country's financial market, such as different degree of development, level of capitalization, degree of sensitivity to shocks and economic crisis, and different time periods of study, empirical evidences are mixed. In other words, conclusions on REITs market efficiency are not consistent. For instance, studies including Liu et al. [28], Zheng [43], Hui and Yam [20], Almudhaf and Hansz [6] and Su et al. [39] find that REITs market is not efficient following the rejection of the random walk hypothesis. On the contrary, other studies conclude that the REITs indices of some countries 
observe martingale behavior, thus making the markets efficient (see [19, 23] and [41]. For a more robust analysis, some studies put other factors that could affect changes in market efficiency into consideration. For example, Jirasakuldech and Knight [22] consider time component and conclude that there is an improvement in the efficiency of REITs market over time. Jirasakuldech and knight [22] and Zhou and Lee [45] reveal that market conditions, such as price level, tax reform and degree of development in the market, are important influencers of variations in market efficiency. Climatic situation was concluded by Lee et al. [26] and Jamal (2013) as the basis of changes in REITs market efficiency. Lee et al. [26] particularly provide support for significant effect of new-moon anomaly on US REITs. They explain that more profits could be earned by investors if REITs are purchased at the onset of a new moon for a re-sale at the end of the season. Recent studies have begun to look into the influence of monetary policy shocks on the performance of the REITs markets. While Marfatia et al. [29] reveal that the US news has a time-varying effect on the global stocks of REIT, Gupta and Marfatia [18] indicate that the REITs returns of the emerging markets are positively affected by the quantitative easing policy of the government.

Meanwhile, instead of REITs prices, few studies have examined long memory in the returns series or volatility of REITs. The global study of Liow [27] uses data based on 20 regional and national real estate indices and find evidence in favor of long memory in a number of countries. However, when the samples are splitted into sub-samples, long-memory evidence no longer holds for Asian REITs market. Zhou [44] also discovers long memory for 10 REITs markets, although there is mixed evidence to support the attribution of the persistence to the presence of structural breaks. Assaf [7], on the other hand, uniquely examines long memory and shifts in level in the returns and volatility of REITs for 5 countries. The long-memory test employed in the study suggests that volatility exhibits strong long memory, but a weak evidence is noticed in the returns. In addition, the modified GPH estimator further gives support to a short memory model with a level shift, as against long-memory model for 3 countries including Hong Kong, Japan and the USA.

With the USA being the origin of the REITs, it has received a reasonable amount of studies on the efficiency of the market. They include the foremost studies of Kuhle and Alvayay [24] and Nelling and Gyourko [33], and subsequent ones (see $[5,7,26,39]$, inter alia). Varying results have also been reported for the country. For example, while Aguilar et al. [5] and Su et al. [39] show that the REITs market is efficient, Lee et al. [26] report contrary evidence as a result of the effect of new-moon anomaly. Other studies that kick against the efficient market hypothesis for the REITs market based on the use of returns or volatility series include Cotter and Stevenson [13] and Assaf [7].

Indeed, despite the numerous studies that have been carried out on the market efficiency of REITs, especially in the USA, two deficiencies are still noticed in the literature, from which this study derives its contribution. The first relates to the consideration of the likely effect of the global financial crisis of 2008. Is there any change in the efficiency of the market after the crisis? Does the volatility in REITs become more persistent or less so during and after the crisis? These questions are important in making decisions around the possibility of making abnormal returns by investors after the crisis, as well as for the policy makers to know if shocks will be permanent or transitory. To the best of our knowledge, only few studies have addressed these issues (see [11, 31]). Some of the specific US-based studies on the effect of the crisis on the REITs do not pay strict focus to market efficiency (see, for example, $[9,10]$ which focus on dividend policy, rather than market efficiency).

The second gap is in terms of methodology. The empirical literature on REITs market efficiency has witnessed a number of techniques. The early techniques include the unit root test and variance ratio test (see [23, 25], Aguilar, 2015; [37, 38]. The traditional variance ratio test was later improved and consequently employed by other studies including Almudhaf and Hansz [6], and Zhang and Sun [42]. Many other uncommon techniques such as bootstrap autocorrelation test, binomial option pricing method, present value model and Hurst exponent are now also being used by researchers to measure REITs market efficiency (see [19, 28, 39]. Unfortunately, all these techniques, except the Hurst exponent, follow the efficient market hypothesis which explains the market on a paradigm of linearity [28]. However, the complexities and structural changes in financial markets have resulted in the inability to describe them with linear models. There are empirical studies that have proven the nonlinear situations of financial markets (see [1, 15, 32], for instance), with Wen et al. [40] indicating that they often observe thick tails and sharp peaks. The simulation results of Granger and Hyung [17] and Mikosch and Starica [30] also show that the long memory observed in time series can be spurious in the presence of structural breaks. In addition, Assaf [7] shows that REITs returns and volatilities that have long memory imply the existence of underlying fractal structure which linear models cannot handle. In light of this, we employ an advanced technique which is able to handle these complexities. Unlike the techniques highlighted above, the fractional integration approach performs better in the presence of structural breaks, fractional integration and trend-stationarity 
[2-4], and [16]. Therefore, we apply the fractional integration method on the logged and squared returns ${ }^{1}$ series of REITs.

The layout of the remainder of this paper is structured thus: "Methods" Section develops the methodology of the study, while "Results and discussion" Section describes the data and the results of the preliminary tests. "Conclusions" Section discusses the results, and Sect. 5 gives the concluding remarks.

\section{Methods}

In this paper, the analysis of the efficiency of US REITs market is based on the approach of fractional integration. To start with, we define a process with $\mathrm{I}(0)$ (i.e., covariance stationary or white noise) process which has a spectral density that is both positive and finite at the zero frequency. On this note, the fractionally integrated model of order $d\left(x_{t} \sim I(d)\right)$ is given as:

$$
(1-B)^{d} x_{t}=\mu_{t} ; t=1,2, \ldots
$$

with B being the lag operator $\left(B x_{t}=x_{t-1}\right)$, and $\mu_{t}$ is $\mathrm{I}(0)$ process. $d$ is the differencing parameter that determines the degree of persistence of the series. Ideally, fractional integration occurs if $d$ takes non-integer value. The binomial expression of $(1-B)^{d}$ in terms of infinite order with monotonically declining weights is further expressed as:

$$
\begin{aligned}
(1-B)^{d}=\sum_{i=0}^{\infty}\left(\begin{array}{c}
d \\
i
\end{array}\right)(-1)^{i} B^{i}= & -d B+\frac{d(d-1)}{2 !} B^{2} \\
& -\frac{d(d-1)(d-2)}{3 !} B^{3}+\cdots
\end{aligned}
$$

Therefore,

$$
\begin{aligned}
(1-B)^{d} x_{t}= & x_{t}-d x_{t-1}+\frac{d(d-1)}{2 !} x_{t-2} \\
& -\frac{d(d-1)(d-2)}{3 !} x_{t-3}+\cdots
\end{aligned}
$$

Persistence becomes stronger as the differencing parameter, $d$ increases. A positive value of $d$ (i.e., $d>0$ ) suggests that $x_{t}$ has long memory, implying that there is a strong degree of dependence between observations in far distant time. Moreover, a value of $d$ between 0 and $0.5(0<d<0.5)$ indicates that $x_{t}$ observes stationary mean reversion (i.e., covariance stationary), while a value of $d$ in the range $0.5 \leq d<1$ is a case of non-stationary mean reversion property of $x_{t}$. Whatever be the case, if $d<1$,

\footnotetext{
${ }^{1}$ Many empirical studies have used either or both absolute and squared returns as proxies for volatility (see [7,13 and 16$]$. Nonetheless, a few studies such as Stevenson [38], Rogers et al. [36], and Begiazi et al. [8] determine the REITs market volatility via the GARCH-based models.
}

the series is said to observe a mean reverting behavior, implying that the effects of shocks will be the transitory, as they tend to die out in the long run. However, if $d \geq 1$, the series is strictly non-stationary and highly persistent, indicating that, unless strong policy measures are formulated, the effects of shocks will be permanent.

Now, the differencing parameter, $d$, will be estimated using two methods: parametric and semiparametric. This parametric approach of Robinson [34] is based on the Whittle function in the frequency domain (see [14]. Whether or not the series is non-stationary, Robinson [34] proves that this approach is valid. Therefore, the first difference of the series is not needed to be taken in order that the series become stationary before estimation. Hence, we estimate a model of the form:

$$
y_{t}=\delta^{\prime} z_{t}+x_{t}, t=1,2, \ldots
$$

where the time series under observation is $y_{t}$, and $z_{t}$, which is a vector of deterministic terms, may include a constant and a linear time trend. Based on Eqs. (1) and (5) therefore, the null hypothesis is:

$$
H_{0}: d=d_{0}
$$

Furthermore, we also employ the semiparametric Whittle approach of Robinson [35], which is defined as:

$$
\hat{d}=\arg \min _{d}\left(\log \overline{C(d)}-2 d \frac{1}{w} \sum_{i=1}^{w} \log \gamma_{i}\right),
$$

For

$$
\begin{aligned}
& d \in(-1 / 2,1 / 2) ; \overline{C(d)}=\frac{1}{w} \sum_{i=1}^{w} I\left(\gamma_{i}\right) \gamma_{i}^{2 d}, \\
& \gamma_{i}=\frac{2 \pi i}{T}, \frac{1}{w}+\frac{w}{T} \rightarrow 0,
\end{aligned}
$$

where the bandwidth parameter is $w$, and the periodogram of the time series is $I\left(\gamma_{i}\right)$. Robinson [35] further shows that, given that the fourth moment is finite and other mild conditions are fulfilled, $\sqrt{w}\left(\widehat{d}-d_{0}\right) \rightarrow d N\left(0, \frac{1}{4}\right)$ as $T \rightarrow \infty$, where $d_{0}$ remains the ideal value of $d$, and under an extra condition that $w \rightarrow \infty$ slower than $\mathrm{T}$.

\section{Results and discussion}

Preliminary analysis

Following the objective of this paper, which is to examine the market efficiency of the US REITs market, the data used are the Wilshire REITs price index and REITs total market index of the USA. The use of REITs total market index is premised on the need to show that the findings of 
Table 1 Statistical properties of series

\begin{tabular}{llllll}
\hline & \multicolumn{2}{l}{ Logged series } & \multicolumn{2}{l}{ Squared returns } \\
\cline { 2 - 3 } \cline { 5 - 6 } & Price index & Market index & & Price index & Market index \\
\hline Mean & 5.2094 & 8.2775 & & 0.0003 & 0.0003 \\
Maximum & 5.7701 & 9.4142 & & 0.0485 & 0.0485 \\
Minimum & 4.1955 & 6.9613 & & 0.0000 & 0.0000 \\
Std. Dev & 0.3711 & 0.7021 & & 0.0015 & 0.0014 \\
Skewness & -0.4285 & -0.1952 & & 14.2627 & 15.1599 \\
Kurtosis & 1.8771 & 1.7142 & & 297.7288 & 336.6815 \\
Jarque-Bera & 439.7546 & 453.3688 & & $19,318,551$ & $28,182,601$ \\
(Prob.) & $(0.0000)$ & $(0.0000)$ & & $(0.0000)$ & $(0.0000)$ \\
Observation & 5289 & 6026 & & 5288 & 6025 \\
\hline
\end{tabular}

the paper are robust to different data measurement. Both series are therefore sourced from the Federal Reserve of the USA (https://fred.stlouisfed.org) and are measured on daily frequency. While the REITs price index covers December, 31, 1998, to January 8, 2020, REITs total market index covers January 31, 1996, to January 8, 2020. Extending the objective of the study to analyze the market efficiency for the periods before and after the global financial crisis of 2008, the long historical data are further partitioned into pre-crisis, crisis and post-crisis periods, using 2008 as the basis of division. The basis of data disaggregation follows the suggested break dates of the unit root test (see Table 1) and the significant spike around 2008 as evidenced in the graphical trends (see Figs. 1 and 2). Furthermore, two distinctive features of the data are employed for analysis. The natural logarithmic transformation is first taken to estimate the fractional differencing parameter, while the squared returns of the series are computed in order to further assess long-memory behavior in the volatility of REITs.

The plots of the logged values of the series and the squared returns are given in Figs. 1 and 2. Comparing the graphs, it is obviously seen that REITs total market index (Fig. 2) mirrors the REITs price index (Fig. 1), as their trend patterns seem to look alike. Moreover, it could be deduced that there is a significant spike in the two variables for both logged and squared returns series around 2008 which corresponds to the period of the global financial crisis. At that time, the REITs market experienced a great meltdown that saw to the sharp fall in the prices of the asset. The impact of the financial turmoil is also reflected in the squared returns. Although the series began to pick up again after the crisis, the plots in both figures clearly show that the trends of the logged series seem to be flatter, thus indicating that daily growth is slower when compared to the pre-crisis period. This is notwithstanding the fact that REITs values are higher after the crisis, i.e., the values are higher, but the growth speed seems to be slower judging by how flat the trend becomes. Based on this, it is expedient to unravel the

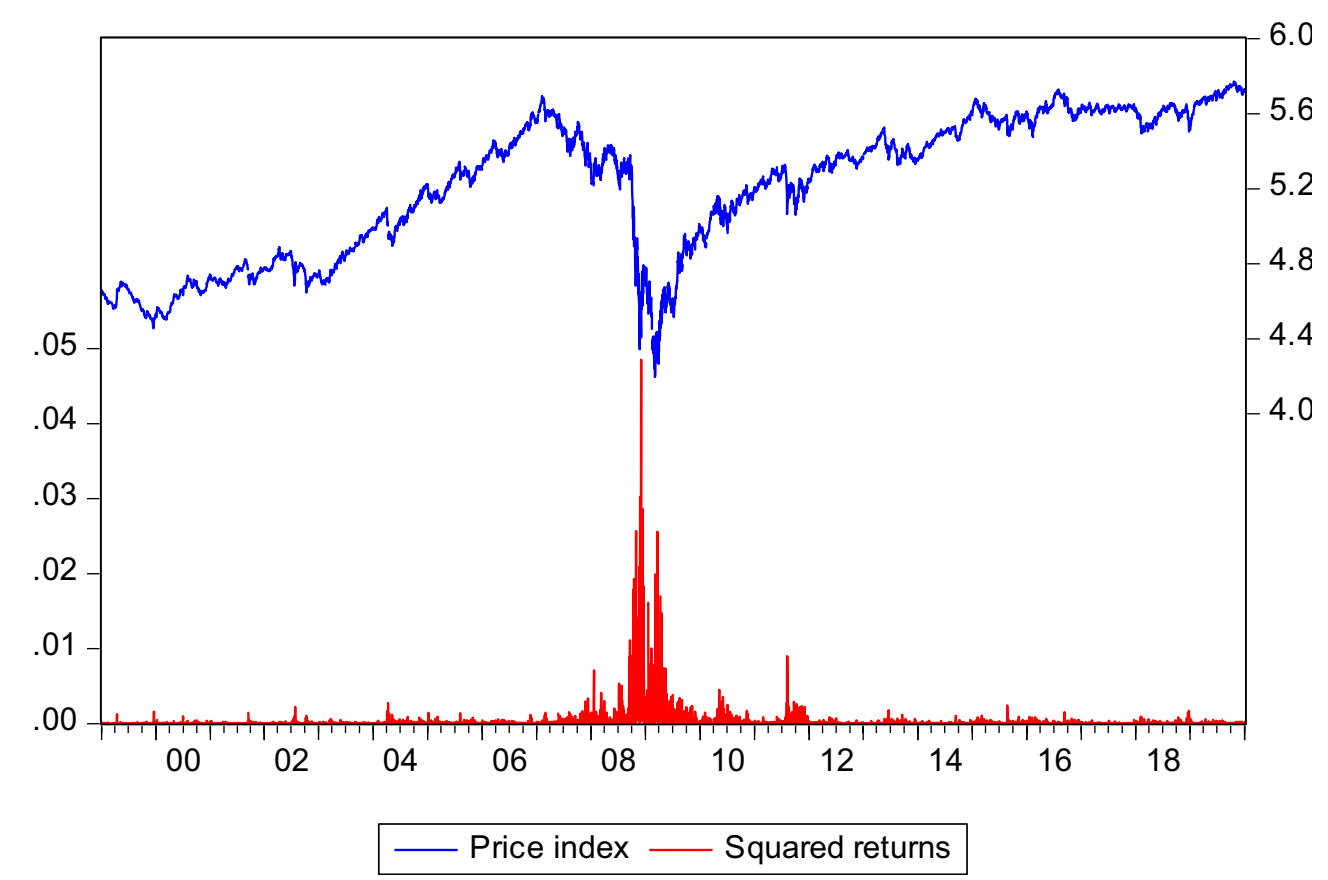

Fig. 1 Trends of REITs price index and its squared returns 


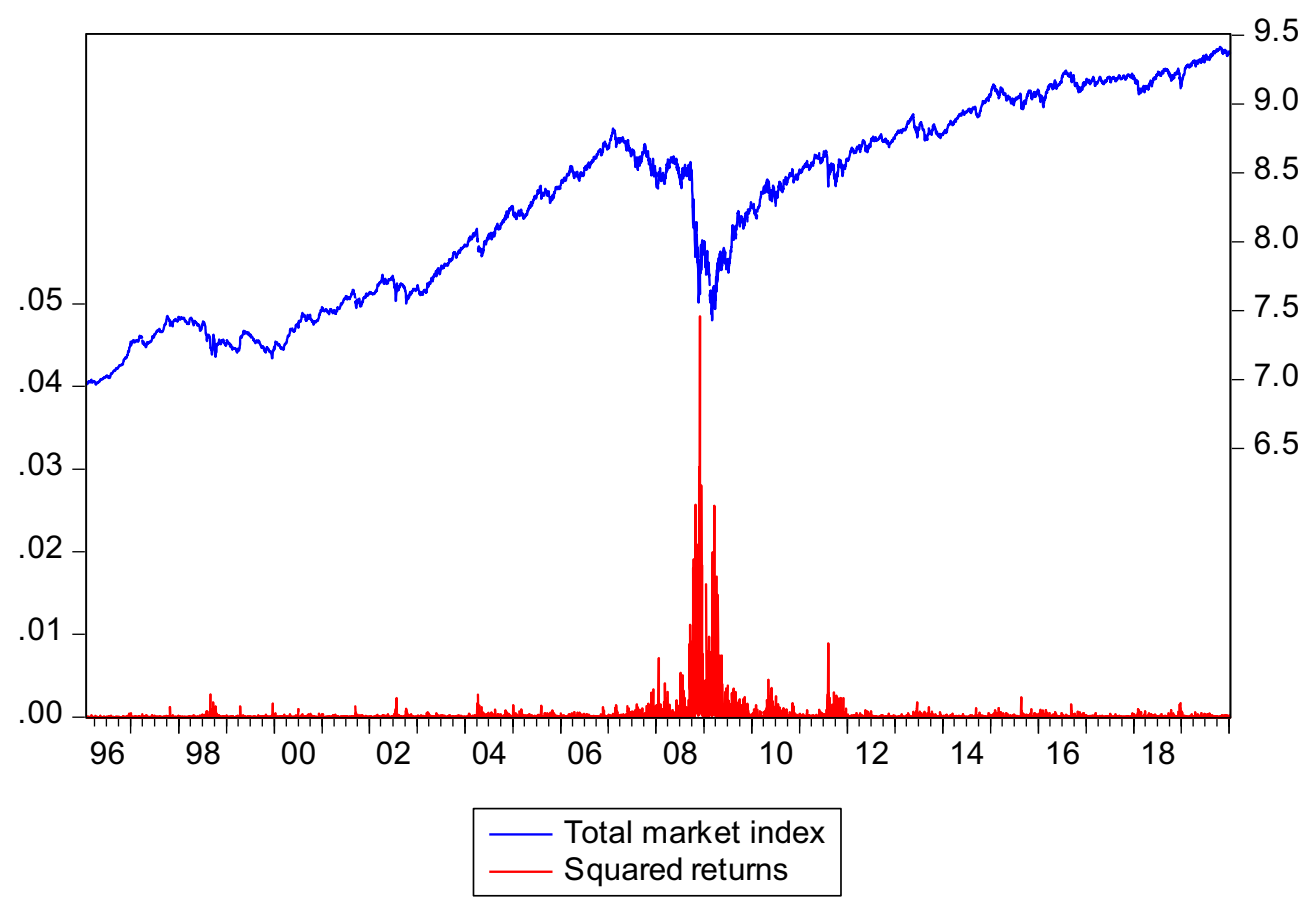

Fig. 2 Trends of REITs total market index and its squared Returns

Table 2 Unit root tests results

\begin{tabular}{|c|c|c|c|c|c|c|c|c|}
\hline \multirow[t]{3}{*}{ Variables } & \multicolumn{4}{|c|}{ Unit root without structural breaks } & \multicolumn{4}{|c|}{ Unit root with structural breaks } \\
\hline & \multicolumn{2}{|l|}{ ADF } & \multicolumn{2}{|l|}{ PP } & \multicolumn{4}{|c|}{ Perron-Vogelsang } \\
\hline & & $\mathrm{I}(0)$ & $\mathrm{I}(1)$ & $\mathrm{I}(0)$ & $\mathrm{I}(1)$ & Coeff & t-test & Break date \\
\hline \multirow[t]{2}{*}{ Logged Series } & Price index & -2.567 & $-86.385^{* * *}$ & -2.486 & $-86.634^{* * *}$ & 0.992 & -4.731 & $5 / 19 / 08$ \\
\hline & Market index & -2.703 & $-91.230^{* * *}$ & -2.630 & $-92.149^{* * *}$ & 0.994 & -4.163 & $5 / 15 / 08$ \\
\hline \multirow[t]{2}{*}{ Squared Returns } & Price index & $-4.913^{* * *}$ & ----- & $-103.759^{* * *}$ & ----- & $0.835^{* * *}$ & -9.722 & $12 / 1 / 08$ \\
\hline & Market index & $-4.803^{* * *}$ & ----- & $-112.095^{* * *}$ & ---- & $0.862^{* * *}$ & -9.680 & $12 / 1 / 08$ \\
\hline
\end{tabular}

${ }^{* * *}$ represents significance at $1 \%$ critical level

likely alteration the financial crisis might have done to the efficiency of the market.

Continuing with the preliminary analyses, Table 1 reports the statistical properties of the level-series and their squared returns. Expectedly, the mean, maximum and minimum values of the total market index are greater than those of price index. The standard deviation statistic is still higher for the total market index, but generally low for the two series, implying that their individual data points are not too far from their average values. This tendency is further confirmed by how their minimum and maximum values are not far apart. We reject the null hypothesis of normal distribution for both series following the significance of the Jarque-Bera test. Considering the squared returns, the values appear similar in virtually all cases, except for the measures of normality of the series. They are also not found to be normally distributed. Lastly under this section, we provide evidence for the unit root properties of the all the series. The results are not different from expected. For robustness, two classes of unit root tests are employed: unit root without structural breaks (Augmented Dickey-Fuller and Philips Perron tests) and unit root with structural breaks. Presented in Table 2, all the three tests suggest that the logged series are not stationary. On the contrary, the unit root null hypothesis is rejected for the squared returns. The unit root test with structural breaks further suggests one break date each for the series, and interestingly, they are all in 2008 which was the year of the crisis. 
Table 3 Estimates of $d$ for the fully sampled logged series

\begin{tabular}{llll}
\hline Series & No terms & An intercept & A linear trend \\
\hline White noise & & & \\
Price index & 0.9056 & 0.8882 & $\mathbf{0 . 8 8 4 7}$ \\
& $(0.0088)$ & $(0.0094)$ & $\mathbf{( 0 . 0 0 9 6 )}$ \\
Market index & 0.9493 & 0.9046 & $\mathbf{0 . 8 9 2 9}$ \\
& $(0.0067)$ & $(0.1245)$ & $\mathbf{( 0 . 0 0 9 1 )}$ \\
Autocorrelation & & & \\
Price index & $\mathbf{0 . 9 7 0 6}$ & 0.9607 & -0.1140 \\
& $\mathbf{( 0 . 0 1 2 2 )}$ & $(0.0147)$ & $(0.0097)$ \\
Market index & 0.9906 & $\mathbf{0 . 9 7 4 6}$ & -0.1058 \\
& $(0.0076)$ & $\mathbf{( 0 . 0 1 3 4 )}$ & $(0.0092)$ \\
\hline
\end{tabular}

Significant values based on the deterministic terms are in bold, while the values in parentheses are the standard errors

This corroborates the spike experienced in our graphical analysis, hence the need to use a technique that is able to capture structural breaks, and also evaluate the behavior of the market after the crisis.

\section{Empirical results}

The main idea of this empirical analysis is based on the examination of persistence in the REITs market using the fractional integration technique. Hence, the fractional differencing parameter, $d$, is estimated in the model given as:

$$
y_{t}=\alpha_{0}+\alpha_{1} t+x_{t} ;(1-B)^{d} x_{t}=\mu_{t}, t=1,2, \ldots
$$

In estimating $d$, the three conventional cases of: the absence of deterministic terms, a constant, and a constant with a linear time trend, are put into consideration. The results are presented under different assumptions of uncorrelated (white noise) and correlated disturbance term, $\mu_{t}$. In addition, since this study is not only interested in examining the efficiency of the US REITs market over time, but its behavior before and after the 2008 global financial crisis, the long series is further partitioned into two, each covering the pre-crisis and post-crisis periods. Then, the differencing parameter $d$ is re-estimated for each period in order to determine if market efficiency is induced or worsened by the crisis.

\section{Results for full sample}

Starting with the full sample analysis, the results for the estimates of $d$ are reported in Tables 3 and 4 for the logged series and squared returns, respectively. For the logged series (Table 3), linear time trend seems to be required for both REITs price index and total market index under the white noise case. On the other hand,
Table 4 Estimates of $d$ for the fully sampled volatility series

\begin{tabular}{llll}
\hline Series & No terms & An intercept & A linear trend \\
\hline White noise & & & \\
Price index & $\mathbf{0 . 2 3 7 6}$ & 0.2375 & 0.2376 \\
& $\mathbf{( 0 . 0 0 7 9 )}$ & $(0.0079)$ & $(0.0079)$ \\
Market index & $\mathbf{0 . 2 3 8 1}$ & 0.2381 & 0.2380 \\
& $\mathbf{( 0 . 0 0 7 4 )}$ & $(0.0074)$ & $(0.0074)$ \\
Autocorrelation & & & \\
Price index & $\mathbf{0 . 3 0 1 6}$ & 0.3016 & 0.3016 \\
& $\mathbf{( 0 . 0 1 0 5 )}$ & $(0.0105)$ & $(0.0105)$ \\
Market index & $\mathbf{0 . 3 0 2 2}$ & 0.3022 & 0.3021 \\
& $\mathbf{( 0 . 0 0 9 8 )}$ & $(0.0098)$ & $(0.0098)$ \\
\hline
\end{tabular}

Significant values based on the deterministic terms are in bold, while the values in parentheses are the standard errors

when autocorrelation is put into consideration, no deterministic terms are required for the REITs price index, while the REITs total market index only requires intercept. The estimates of both series seem not to be significantly different under each case of uncorrelated errors and correlated errors. For instance, when the errors are assumed to be uncorrelated, both series suggest long memory and mean reverting behavior, given that $d$ estimates fall within the $(0.5,1)$ range. In the case of correlated errors, however, the unit root hypothesis $(d=1)$ cannot be strictly rejected for the two series. Moreover, estimation under the correlated errors produces consistent results even at higher autoregressive orders. Thus, the $d$ estimates under the case of autocorrelation are relied on. For the volatility series, proxied by the squared returns of the REITs series, Table 4 reports for the full sample that the $d$ estimates fall within the $(0,0.5)$ range, irrespective of whether white noise or autocorrelation is assumed for the disturbance terms. These findings imply stationary mean reverting and long-memory behavior for the volatility series.

The findings of the parametric approach are affirmed by the semiparametric approach based on Whittle estimation. Similar to the outcomes of the parametric technique, Table 5 shows that the null hypothesis of unit root cannot be rejected for the logged series as the $d$ estimates are not significantly different from 1 in higher number of cases. Table 6 also provides similar evidence in favor of mean reverting long-memory behavior of the REITs squared returns.

\section{Results for pre-and post-crisis periods}

It is believed in this study that, owing to the heat of the global financial crisis of 2008, and particularly with the 
Table 5 Semiparametric estimates of $d$ for the fully sampled logged series

\begin{tabular}{lllllllllll}
\hline $\mathbf{w}$ & $\mathrm{T}^{0.4}$ & $\mathrm{~T}^{0.45}$ & $\mathrm{~T}^{0.5}$ & $\mathrm{~T}^{0.55}$ & $\mathrm{~T}^{0.6}$ & $\mathrm{~T}^{0.65}$ & $\mathrm{~T}^{0.7}$ & $\mathrm{~T}^{0.75}$ & $\mathrm{~T}^{0.76}$ & $\mathrm{~T}^{0.79}$ \\
\hline Price index & $\mathbf{1 . 0 0 7 6}$ & $\mathbf{1 . 0 0 5 6}$ & $\mathbf{1 . 0 1 2 0}$ & $\mathbf{1 . 0 1 4 0}$ & $\mathbf{1 . 0 0 3 7}$ & 1.0600 & $\mathbf{1 . 0 3 6 6}$ & 1.1059 & 1.0831 & 1.1836 \\
Market index & $\mathbf{1 . 0 0 9 2}$ & $\mathbf{1 . 0 0 7 2}$ & $\mathbf{1 . 0 1 6 1}$ & $\mathbf{1 . 0 2 1 8}$ & $\mathbf{1 . 0 1 5 7}$ & $\mathbf{1 . 0 1 5 6}$ & $\mathbf{1 . 0 4 5 5}$ & 1.1722 & 1.1722 & $\mathbf{0 . 9 8 7 6}$
\end{tabular}

$\mathrm{w}$ and $\mathrm{T}$ are the bandwidth number and the total number of observations, respectively. Values in bold are those cases where the $d$ estimates are not significantly different from 1

Table 6 Semiparametric estimates of $d$ for the fully sampled volatility series

\begin{tabular}{|c|c|c|c|c|c|c|c|c|c|c|}
\hline w & $\mathrm{T}^{0.4}$ & $\mathrm{~T}^{0.45}$ & $\mathrm{~T}^{0.5}$ & $\mathrm{~T}^{0.55}$ & $\mathrm{~T}^{0.6}$ & $\mathrm{~T}^{0.65}$ & $\mathrm{~T}^{0.7}$ & $\mathrm{~T}^{0.75}$ & $\mathrm{~T}^{0.76}$ & $\mathrm{~T}^{0.79}$ \\
\hline Price index & 0.6736 & 0.5369 & 0.6544 & 0.6068 & 0.3596 & 0.3060 & 0.2381 & 0.2432 & 0.2362 & 0.2327 \\
\hline Market index & 0.6550 & 0.5674 & 0.6127 & 0.6600 & 0.3919 & 0.3034 & 0.2332 & 0.2408 & 0.2408 & 0.2211 \\
\hline
\end{tabular}

$\mathrm{w}$ and $\mathrm{T}$ are the bandwidth number and the total number of observations, respectively. Values in bold are those cases where the $d$ estimates are significantly lower than 0.5

USA being at the forefront of the event, the efficiency of the US REITs market could be significantly altered. As an example, Assaf [7] shows that the behavior of most series significantly changed during the crisis. Hence, this study also attempts to evaluate and compare the efficiency of the US REITs market for the periods before, during and after the global financial turmoil of 2008. To do this, the full sampled data are partitioned into three periods using 2008 , which is the main year of the crisis, as the basis of division. By implication, the pre-crisis period runs from the start date of the fully sampled data to December, 31 , 2007, while the crisis period covers January 02, 2008, and December 31, 2008. The post-crisis period begins from January, 2, 2009, to the last date of the fully sampled data.

In Table 7, the estimates of $d$ based on the parametric technique are presented for the logged prices for the sub-sampled periods. Irrespective of the assumptions made on the disturbance terms (i.e., under the two cases of white noise and autocorrelated errors), it is discovered for both series that $d$ is not significantly different from 1 for the pre-crisis sample. This means that the $d=1$ unit root hypothesis, which is related to the efficiency of the financial market, cannot be rejected. The table further shows for the crisis and post-crisis periods that the estimates of $d$ are significantly below 1 , in favor of the rejection of the unit root hypothesis. This indicates that the crisis led to the inefficiency of the REITs market. Turning to the squared returns, it is obviously seen from Table 8 that long memory and mean reversion are still found for all the periods. However, reversion is faster during the pre-crisis period than the crisis and the post-crisis periods.

Now focusing on the estimates based on the semiparametric approach, market efficiency is still supported for the pre-crisis period following a larger part of the estimates being insignificantly different from 1 across the
Table 7 Estimates of $d$ for the pre- and post-crisis periods (logged series)

\begin{tabular}{|c|c|c|c|c|}
\hline Series & & No terms & An intercept & A linear trend \\
\hline \multicolumn{5}{|l|}{ White noise } \\
\hline \multirow[t]{6}{*}{ Price index } & Pre-crisis & 1.0254 & 1.0518 & 1.0494 \\
\hline & & $(0.0138)$ & $(0.0179)$ & $(0.0182)$ \\
\hline & Crisis & 0.8477 & 0.8499 & 0.8263 \\
\hline & & $(0.0413)$ & $(0.0419)$ & $(0.0446)$ \\
\hline & Post-crisis & 0.9290 & 0.8660 & 0.8491 \\
\hline & & (0.0109) & $(0.0126)$ & $(0.0135)$ \\
\hline \multirow[t]{6}{*}{ Market index } & Pre-crisis & 1.0240 & 1.0864 & 1.0817 \\
\hline & & $(0.0080)$ & $(0.0156)$ & $(0.0160)$ \\
\hline & Crisis & 0.8435 & 0.8456 & 0.8256 \\
\hline & & $(0.0418)$ & $(0.0423)$ & $(0.0447)$ \\
\hline & Post-crisis & 0.9480 & 0.8764 & 0.8484 \\
\hline & & $(0.0098)$ & $(0.0120)$ & $(0.0135)$ \\
\hline \multicolumn{5}{|l|}{ Autocorrelation } \\
\hline \multirow{6}{*}{ Price index } & Pre-crisis & 0.9743 & 0.0521 & 0.9481 \\
\hline & & $(0.0181)$ & $(0.0183)$ & $(0.0313)$ \\
\hline & Crisis & 0.9236 & 0.9344 & 0.9085 \\
\hline & & $(0.0600)$ & $(0.0626)$ & $(0.0683)$ \\
\hline & Post-crisis & 0.9290 & 0.8660 & 0.9394 \\
\hline & & $(0.0109)$ & $(0.0126)$ & $(0.0216)$ \\
\hline \multirow[t]{6}{*}{ Market index } & Pre-crisis & 0.9974 & 1.0046 & 0.0913 \\
\hline & & $(0.0093)$ & $(0.0387)$ & $(0.0172)$ \\
\hline & Crisis & 0.9194 & 0.9288 & 0.9069 \\
\hline & & $(0.0613)$ & $(0.0633)$ & $(0.0684)$ \\
\hline & Post-crisis & 1.0040 & 0.9632 & 0.9390 \\
\hline & & $(0.0107)$ & $(0.0192)$ & $(0.0216)$ \\
\hline
\end{tabular}

Significant values based on the deterministic terms are in bold, while the values in parentheses are the standard errors

chosen bandwidths (see Table 9). In similar version to the parametric estimates for the crisis and post-crisis periods, we also find evidence for inefficiency of the REITs 
Table 8 Estimates of $d$ for the pre- and post-crisis periods (volatility series)

\begin{tabular}{|c|c|c|c|c|}
\hline Series & & No terms & An intercept & A linear trend \\
\hline White noise & & & & \\
\hline Price index & Pre-crisis & 0.1951 & 0.1950 & - \\
\hline & & $(0.0139)$ & (0.0139) & \\
\hline & Crisis & 0.2107 & 0.2107 & 0.1177 \\
\hline & & $(0.0387)$ & $(0.0387)$ & $(0.0431)$ \\
\hline & Post-crisis & 0.2556 & 0.2567 & 0.2406 \\
\hline & & $(0.0115)$ & $(0.0115)$ & $(0.0115)$ \\
\hline Market index & Pre-crisis & 0.1970 & 0.1970 & - \\
\hline & & $(0.0120)$ & $(0.0120)$ & \\
\hline & Crisis & 0.2111 & 0.2111 & 0.1184 \\
\hline & & $(0.0387)$ & (0.0388) & $(0.0431)$ \\
\hline & Post-crisis & 0.2557 & 0.2569 & 0.2407 \\
\hline & & $(0.0115)$ & $(0.0115)$ & $(0.0115)$ \\
\hline Autocorrelatiol & & & & \\
\hline Price index & Pre-crisis & 0.2576 & 0.2576 & - \\
\hline & & $(0.0149)$ & (0.0199) & \\
\hline & Crisis & 0.2798 & 0.2799 & 0.1708 \\
\hline & & $(0.0506)$ & $(0.0507)$ & $(0.0595)$ \\
\hline & Post-crisis & 0.3195 & 0.3225 & 0.3027 \\
\hline & & $(0.0157)$ & $(0.0156)$ & $(0.0155)$ \\
\hline Market index & Pre-crisis & 0.2605 & 0.2605 & - \\
\hline & & $(0.0174)$ & $(0.0174)$ & \\
\hline & Crisis & 0.2798 & 0.2799 & 0.1713 \\
\hline & & $(0.0506)$ & $(0.0507)$ & $(0.0594)$ \\
\hline & Post-crisis & 0.3210 & 0.3240 & 0.3042 \\
\hline & & $(0.0158)$ & $(0.0157)$ & $(0.0156)$ \\
\hline
\end{tabular}

Significant values based on the deterministic terms are in bold, while the values in parentheses are the standard errors

market, although in favor of $d>1$ in this case. Hence, while the parametric method supports mean reversion, the semiparametric method gives support to high degree of persistence. Notwithstanding this relative difference, they both commonly suggest market inefficiency after the global financial crisis. The results for the squared returns are not really different from those obtained under the parametric method, as reported in Table 10. Long memory and mean reverting behavior are still noticed for the series across the three periods, but such reversion seems to be slower after the crisis.

\section{Conclusion}

This paper is mainly geared towards the examination of the degree of persistence of the REITs series, and by implication the efficiency of the REITs market, of the US using the fractional integration long-memory technique. The effect of the 2008 global financial crisis on the efficiency of the REITs market is further examined by partitioning the historical data into three sub-samples using 2008, which was the year the crisis took its hit on the financial market of the country, as the basis of disaggregation. As earlier noted, the choice of the fractional integration technique, as against other commonly used techniques, bothers on its better performance in the presence of structural breaks, trend-stationarity or fractional integration. For robustness, both parametric and semiparametric methods of the fractional integration technique are used.

The results show for the aggregate sample that the random walk hypothesis, associated with efficiency of the financial market, cannot be rejected. On disaggregating the series, it is discovered that the REITs market was efficient before the break out of the financial crisis, but the efficiency was eroded during and after it. Like in the case of the aggregate sample, the random walk hypothesis could not be rejected during the pre-crisis period, thus indicating that the market was efficient. However, the crisis and post-crisis periods witnessed a turnaround as the random walk hypothesis is strongly rejected in favor of $d<1$ (mean reversion) in a large number of cases, indicating market inefficiency. Only in the case of the semiparametric technique for the REITs index do a reasonably large number of the chosen bandwidths reject the random walk hypothesis to support $d>1$. Notwithstanding, it still depicts that the market is inefficient. In addition, it is found that volatility in the REITs series observes

Table 9 Semiparametric estimates of $d$ for the pre- and post-crisis periods (logged series)

\begin{tabular}{llllllllllll}
\hline $\boldsymbol{w}$ & & $\mathrm{T}^{\mathbf{0 . 4}}$ & $\mathrm{T}^{0.45}$ & $\mathrm{~T}^{0.5}$ & $\mathrm{~T}^{0.55}$ & $\mathrm{~T}^{0.6}$ & $\mathrm{~T}^{0.65}$ & $\mathrm{~T}^{0.7}$ & $\mathrm{~T}^{0.75}$ & $\mathrm{~T}^{0.76}$ & $\mathrm{~T}^{0.79}$ \\
\hline Price index & Pre-crisis & $\mathbf{1 . 0 1 0 5}$ & $\mathbf{1 . 0 2 0 5}$ & $\mathbf{1 . 0 3 4 7}$ & $\mathbf{1 . 0 3 3 8}$ & $\mathbf{1 . 0 3 5 8}$ & 1.0607 & $\mathbf{1 . 0 3 7 2}$ & 1.0724 & 1.0724 & 1.1728 \\
& Crisis & $\mathbf{1 . 0 4 8 3}$ & $\mathbf{1 . 1 0 1 2}$ & $\mathbf{1 . 1 5 1 1}$ & $\mathbf{1 . 2 1 3 2}$ & $\mathbf{1 . 6 6 4 2}$ & 1.5299 & $\mathbf{1 . 3 4 7 7}$ & $\mathbf{1 . 0 6 0 9}$ & 0.7039 & 0.7039 \\
& Post-crisis & 1.0052 & 0.9976 & 1.0189 & 1.0398 & $\mathbf{1 . 0 5 0 5}$ & $\mathbf{1 . 0 9 0 6}$ & $\mathbf{1 . 1 2 4 2}$ & $\mathbf{1 . 1 6 0 8}$ & $\mathbf{1 . 1 2 4 0}$ & $\mathbf{1 . 0 6 5 7}$ \\
\multirow{2}{*}{ Market index } & Pre-crisis & $\mathbf{1 . 0 1 4 1}$ & $\mathbf{1 . 0 1 1 7}$ & $\mathbf{1 . 0 2 0 5}$ & $\mathbf{1 . 0 1 4 1}$ & $\mathbf{1 . 0 2 9 2}$ & 1.0753 & 1.1004 & 1.1059 & $\mathbf{0 . 9 8 9 7}$ & 1.1051 \\
& Crisis & $\mathbf{1 . 0 5 3 2}$ & $\mathbf{1 . 1 0 9 3}$ & $\mathbf{1 . 1 5 9 2}$ & $\mathbf{1 . 2 2 4 4}$ & $\mathbf{1 . 6 6 4 2}$ & $\mathbf{1 . 5 6 7 6}$ & $\mathbf{1 . 3 7 7 7}$ & $\mathbf{1 . 0 6 7 2}$ & $\mathbf{0 . 7 0 3 3}$ & 0.7033 \\
& Post-crisis & 1.0080 & 1.0023 & 1.0185 & 1.0353 & 1.0412 & $\mathbf{1 . 0 8 4 3}$ & $\mathbf{1 . 1 1 7 2}$ & $\mathbf{1 . 1 5 2 2}$ & $\mathbf{1 . 2 1 9 7}$ & $\mathbf{1 . 0 5 0 0}$ \\
& & &
\end{tabular}

$w$ and $T$ are the bandwidth number and the total number of observations, respectively. For pre-crisis period, values in bold are those cases where the d estimates are not significantly different from 1, while for post-crisis period, values in bold are those cases where the d estimates are significantly higher than 1 
Table 10 Semiparametric estimates of $d$ for the pre- and post-crisis periods (volatility series)

\begin{tabular}{llllllllllll}
\hline $\mathbf{w}$ & & $T^{0.4}$ & $T^{0.45}$ & $T^{0.5}$ & $T^{0.55}$ & $T^{0.6}$ & $T^{0.65}$ & $T^{0.7}$ & $T^{0.75}$ & $T^{0.76}$ & $T^{0.79}$ \\
\hline Price index & Pre-crisis & $\mathbf{0 . 2 7 5 0}$ & $\mathbf{0 . 3 4 1 1}$ & $\mathbf{0 . 4 5 8 4}$ & 0.5371 & 0.5127 & $\mathbf{0 . 4 9 2 4}$ & $\mathbf{0 . 3 9 2 5}$ & $\mathbf{0 . 4 5 9 1}$ & $\mathbf{0 . 4 5 9 1}$ & 0.6485 \\
& Crisis & 0.5714 & 0.7335 & 0.9937 & 1.0127 & 0.8181 & 0.7251 & 0.7749 & 0.9648 & 0.7864 & 0.7864 \\
& Post-crisis & 0.7785 & 0.8353 & 0.7296 & $\mathbf{0 . 3 8 9 8}$ & $\mathbf{0 . 2 8 5 1}$ & $\mathbf{0 . 1 8 8 3}$ & $\mathbf{0 . 2 2 6 0}$ & $\mathbf{0 . 1 5 5 4}$ & $\mathbf{0 . 1 9 7 9}$ & $\mathbf{0 . 2 1 6 0}$ \\
\multirow{2}{*}{ Market index } & Pre-crisis & $\mathbf{0 . 4 1 4 1}$ & $\mathbf{0 . 3 3 7 5}$ & $\mathbf{0 . 4 2 0 5}$ & $\mathbf{0 . 4 8 4 1}$ & $\mathbf{0 . 4 1 5 9}$ & $\mathbf{0 . 4 2 9 5}$ & $\mathbf{0 . 3 2 7 9}$ & $\mathbf{0 . 3 5 7 0}$ & $\mathbf{0 . 3 8 8 7}$ & $\mathbf{0 . 4 9 7 8}$ \\
& Crisis & 0.5734 & 0.7349 & 0.9909 & 1.0122 & 0.8152 & 0.7234 & 0.7737 & 0.9651 & 0.7873 & 0.7873 \\
& Post-crisis & 0.7785 & 0.8357 & 0.7267 & $\mathbf{0 . 3 8 8 4}$ & $\mathbf{0 . 2 8 6 3}$ & $\mathbf{0 . 1 8 9 7}$ & $\mathbf{0 . 2 2 6 7}$ & $\mathbf{0 . 1 5 5 6}$ & $\mathbf{0 . 1 9 8 0}$ & $\mathbf{0 . 2 1 5 5}$
\end{tabular}

$w$ and $T$ are the bandwidth number and the total number of observations, respectively. Values in bold are those cases where the $d$ estimates are significantly lower than 0.5

mean reverting long-memory behavior in virtually all cases, although reversion seems to be slower for the postcrisis period than the pre-crisis period. Putting all these together, we can conclude that the US REITs market was in a state of efficiency, until the global financial crisis disrupted the market condition, thus rendering it inefficient.

The findings of this study are important for investors and policy makers. The inefficient state of the market during and after the outbreak of the crisis suggests that market investors or traders can engage trend-trading strategies to predict the future path of the REITs prices with some level of accuracy in order to make excess returns or abnormal profits. On the other hand, the role played by the financial crisis in making the market inefficient particularly makes the policy recommendation to turn to the government. This study suggests that the US government should formulate and implement regulatory and control measures against future occurrence of such crisis. In addition to this, there is a need for a drastic policy by the government to strengthen the REITs market against vulnerability to shocks. Meanwhile, in making attempt to restore efficiency to the REITs market, policies to be put in place should be development-based while putting the unique features of the REITs market in mind.

\section{Abbreviations}

US: United States; REIT: Real estate investment trust; ADF: Augmented DickeyFuller; PP: Philip Perron.

\section{Acknowledgements}

Not applicable.

\section{Authors' contributions}

OBA contributed to conceptualization, writing-original draft preparation, data curation, methodology, analysis. JAO contributed to analysis, writing, validation. GOO contributed to writing, language editing, supervision.

\section{Funding}

Not applicable.

\section{Availability of data and materials}

The country-specific and global series are, respectively, sourced from the databases of the OECD (data.oecd.org) and the Federal Reserve (fred.stlouisfed. org).

\section{Declarations}

Competing interests

Not applicable.

\section{Author details}

'Department of Economics, Federal University of Agriculture, Abeokuta, Nigeria. ${ }^{2}$ Department of Economics, Tai Solarin University of Education, ljebu-Ode, Nigeria.

Received: 23 March 2021 Accepted: 18 September 2021

Published: 1 November 2021

\section{References}

1. Abbaszadeh MR, Nooghabi MJ, Rounaghi MM (2020) Using Lyapunov's method for analyzing of chaotic behaviour on financial time series data: a case study on Tehran stock exchange. Nat Account Rev 2:297-308

2. Adekoya OB (2019) Modeling of persistence and seasonality in sectoral energy consumption in the USA using fractionally integrated processes: Implications for economic policy. Nat Resour Res. https://doi.org/10. 1007/s11053-019-09599-x

3. Adekoya OB (2020) Long memory in the energy consumption by source of the United States: fractional integration, seasonality effect and structural breaks. Estud Econ 47:31-48

4. Adekoya OB (2020) Persistence and efficiency of OECD stock markets: Linear and nonlinear fractional integration approaches. Empirical Econ. https://doi.org/10.1007/s00181-020-01913-4

5. Aguilar, M., Boudry, W. and Connolly, R. (2015). Cross-sectional dynamics of REIT market efficiency. Working paper presented at NAREIT-AREUEA Real Estate Research Conference, New York.

6. Almudhaf F, Hansz AJ (2018) Random walks and market efficiency: evidence from real estate investment trust (REIT) subsectors. Int J Strategy Property Manag 22:81-92

7. Assaf A (2015) Long memory and level shifts in REITs returns and volatility. Int Rev Financ Anal 42:172-182

8. Begiazi K, Asteriou D, Pilbeam K (2016) A multivariate analysis of United States and global real estate investment trusts. IEEP 13:467-482

9. Case B, Hardin WG, Wu Z (2012) REIT dividend policies and dividend announcement effects during the 2008-2009 liquidity crisis. Real Estate Econom 40:387-421

10. Case B, Yang Y, Yildirim Y (2012) Dynamic correlations among asset classes: REIT and stock returns. J Real Estate Finan Econom 44:298-318

11. Chang G-D, Chen C-S (2014) Evidence of contagion in global REITs investment. Int Rev Econ Financ 31:148-158

12. Chen S, Shen C (2012) Examining the stochastic behavior of REIT returns: Evidence from the regime switching approach. Econ Model 29:291-298

13. Cotter J, Stevenson S (2008) Modeling long memory in REITs. Real Estate Econom 36:533-554

14. Dahlhaus R (1989) Efficient parameter estimation for self-similar process. Ann Stat 17:1749-1766

15. Fan Z, Zhang S (2002) Efficiency and fractal market theory of financial markets. Syst Eng Theory Pract 22:13-19 
16. Gil-Alana LA, Gupta R, Shittu OI, Yaya OS (2018) Market efficiency of Baltic stock markets: a fractional integration approach. Physica A 511:251-262

17. Granger CWJ, Hyung N (2004) Occasional structural breaks and long memory with an application to the S\&P 500 absolute stock returns. J Empir Financ 11:399-421

18. Gupta R, Marfatia HA (2018) The impact of unconventional monetary policy shocks in the U.S. on emerging market REITs. J Real Estate Lit 26:175-188

19. Ho KHD, Tay SJ (2016) REIT market efficiency through a binomial option pricing tree approach. J Property Invest Finance 34:496-520

20. Hui ECM, Yam SCP (2014) Can we beat the "buy-and-hold" strategy? Analysis on European and American securitized real estate indices. Int J Strategy Property Manag 18:28-37

21. Jaml, E. (2013). The effectiveness and efficiency of REITs performance in Malaysia. In: Social Science Electronic Publishing.

22. Jirasakuldech B, Knight J (2005) Efficiency in the market for REITs: Further evidence. J Real Estate Portfolio Manag 11:123-132

23. Kleiman R, Payne J, Sahu A (2002) Random walks and market efficiency: evidence from international real estate markets. J Real Estate Res 24:279-298

24. Kuhle J, Alvayay J (2000) The efficiency of equity REIT prices. Jf Real Estate Portfolio Manag 6:349-354

25. Lee M, Chiang K (2004) Substitutability between equity REITs and mortgage REITs. J Real Estate Res 26:95-113

26. Lee MT, Lee MI, Chiu BH, Lee CL (2014) Do lunar phases affect US REIT returns? Invest Anal J 43:67-78

27. Liow KH (2009) Long-term memory in volatility: some evidence from international securitized real estate markets. J Real Estate Finan Econom 39:415-438

28. Liu J, Cheng C, Yang X, Yan L, Lai Y (2019) Analysis of the efficiency of Hong Kong REITs market based on Hurst exponent. Physica A 534:122035. https://doi.org/10.1016/j.physa.2019.122035

29. Marfatia HA, Gupta R, Cakan E (2017) The international REIT's time-varying response to the U.S. monetary policy and macroeconomic surprises. North Am J Econom Finan 42:640-653

30. Mikosch T, Starica C (2004) Nonstationarities in financial time series, the long-range dependence, and the IGARCH effects. Rev Econ Stat 86:378-390

31. Miyakoshi T, Shimada J, Li K (2016) The impacts of the 2008 and 2011 crises on the Japan REIT market. J Japan Int Econom 41:30-40
32. Moradi M, Nooghabi MJ, Rounaghi MM (2021) Investigation of fractal market hypothesis and forecasting time series stock returns for Tehran Stock Exchange and London Stock Exchange. Int J Financ Econ 26:662-678

33. Nelling E, Gyourko J (1998) The predictability of equity REIT returns. J Real Estate Res 16:251-268

34. Robinson PM (1994) Semiparametric analysis of long memory time series. Ann Stat 22:515-539

35. Robinson PM (1995) Gaussian semiparametric estimation of long range dependence. Ann Stat 23:1630-1661

36. Rogers N, Winson-Geideman K, Karafiath I (2014) The impact of trading volume on REIT volatility using the GARCH model. J Real Estate Portfolio 20:167-178

37. Stevenson S (2002) Momentum effects and mean reversion in real estate securities. J Real Estate Res 23:47-64

38. Stevenson S (2002) An examination of volatility spillovers in REIT returns. J Real Estate Portfolio Manag 8:229-238

39. Su J, Cheung A, Roca E (2012) Are securitized real estate markets efficient?: New international evidence based on an improved automatic portmanteau test. Econ Model 29:684-690

40. Wen F, Yang X, Zhou WX (2019) Tail dependence networks of global stock markets. Int J Financ Econ 24:558-567

41. Zhang J (2017) REITs market efficiency analysis based on present-value model. Statist Decis 15:173-177

42. Zhang H, Sun X (2015) Research on market efficiency of REITs based on Wild Bootstrap variance ratio test: Taking Hong Kong as an example. Finan Theory Pract 8:103-107

43. Zheng, Y. (2016). Evidence of market efficiency on Asia-Pacific REITs. https//ir.lib.ntust.edu.tw/handle/987654321/64295

44. Zhou J (2011) Long memory in REIT volatility revisited: Genuine or spurious, and self-similar? J Prop Res 28:213-232

45. Zhou J, Lee JM (2013) Adaptive market hypothesis: Evidence from the REIT market. Appl Finan Econo 23:1649-1662

\section{Publisher's Note}

Springer Nature remains neutral with regard to jurisdictional claims in published maps and institutional affiliations.

\section{Submit your manuscript to a SpringerOpen ${ }^{\circ}$ journal and benefit from:}

- Convenient online submission

- Rigorous peer review

- Open access: articles freely available online

- High visibility within the field

- Retaining the copyright to your article

Submit your next manuscript at springeropen.com 